\title{
Assessment of solar shading strategies in low- income tropical housing: the case of Uganda
}

Arman Hashemi PhD

Senior Lecturer, School of Environment and Technology, University of Brighton,

Brighton, UK (a.hashemi@brighton.ac.uk) (Orcid:0000-0002-6311-000X)

\begin{abstract}
Developing countries in tropical and subtropical areas will be the worst hit by climate change. Very little research has been done to assess the impact of climate change on thermal comfort in low-income housing in these regions. The effects of solar shading strategies and solar absorptance properties of walls and roofs on thermal comfort in Ugandan low-income housing are studied in this paper. Various shading strategies including curtains, roof and window overhangs, veranda and trees as well as effects of painting on solar heat gain and thermal comfort are modelled using EnergyPlus software. An adaptive approach for naturally ventilated buildings defined by the European Committee for Standardization standard BS EN 15251:2007 is used to assess the conditions. According to the results, solar shading is less effective in meeting thermal comfort requirements and it should be used in conjunction with other strategies to achieve desirable results. White painting, in contrast, significantly improved the conditions and significantly reduced the risk of overheating. Solar shading proved to be effective during the hottest periods of the year, reducing the risk of extreme overheating by up to $52 \%$.
\end{abstract}

\section{Notation}

$T_{\mathrm{a}} \quad$ air temperature

$T_{\text {comf }}$ comfortable temperature

$T_{\text {ed-1 }} \quad$ daily mean external temperature for the previous day

$T_{\text {ed-2 }}$ daily mean external temperature for the day before the previous day

$T_{\max } \quad$ maximum comfortable temperature

$T_{\text {op }} \quad$ operative temperature

$T_{\text {out }} \quad$ outside temperature

$T_{\mathrm{r}} \quad$ mean radiant temperature

$\mathrm{T}_{\mathrm{rm}} \quad$ running mean temperature for today weighted with higher influence of recent days

$T_{\text {upp }} \quad T_{\max }+4$

$\alpha \quad$ constant

$\Delta T \quad$ difference between the operative temperature and the maximum acceptable temperature

\section{Introduction}

Located in East Africa, Uganda is one of the most economically deprived countries in the world. Uganda has a population of around 39 million and an area of $241000 \mathrm{~km}^{2}$ (Byakola, 2007; UN Desa, 2014). According to the UN Development Programme (UNDP, 2015), Uganda is ranked 163 out of 188 countries in terms of the human development index (HDI), with an HDI score of $0 \cdot 483$. Around $33 \%$ of the country's population live in severe multidimensional poverty (UNDP, 2015), and over $60 \%$ of its urban population live in slums (EPRC, 2013; Malik, 2014).

Fired brick, adobe, cob, rammed earth, mud and poles, stabilised earth blocks and concrete are currently the prevailing construction materials in many developing countries, including Uganda (Batchelder et al., 1985; Craterre, 2005; Minke, 2001; Perez, 2009; Ruskulis, 2009). The most common walling, flooring and roofing materials in urban areas of the country are brick (84\%) cement/concrete flooring $(71 \%)$ and iron sheet roof $(84 \%)$, respectively (Ubos, 2010). Previous studies indicate that the embodied energy of construction methods and materials is currently the major challenge which requires immediate attention to mitigate negative environmental effects of low-income housing in Uganda (Hashemi et al., 2015a).

Uganda has a tropical climate moderated by an altitude of 1000-1500 m above sea level (Ubos, 2012; UN-Habitat, 2009). Its temperatures range between 16 and $30^{\circ} \mathrm{C}$ (Ubos, 2006), with the hottest period between December and February (Actwatch Group and Pace Uganda, 2013). There are two rainy seasons (Agra, 2010; UN-Habitat, 2009), with the annual rainfall varying between 750 and $2100 \mathrm{~mm}$ (Agra, 2010). Global warming is expected to increase the average air temperature in East African countries by $3-4^{\circ} \mathrm{C}$ during the next 70 years (EMI, 2012). The average temperature in Uganda is also expected to increase by up to $4 \cdot 3^{\circ} \mathrm{C}$ by 2080 (UN-Habitat, 2010). This situation along with inappropriate and defective construction methods and materials (Hashemi et al., 2015a) may deteriorate thermal comfort conditions (Hashemi et al., 2015b), affecting low-income populations, the majority of whom live in single-roomed (NPA, 2010) overcrowded homes (Ubos, 2012) with limited access to facilities to adapt to the new conditions.

According to the UNDP (2015), around 18\% of Ugandan households have access to electricity. Access to energy is more critical, with only $5 \%$ of rural households having access to electricity compared with around 55\% in urban areas (Ubos, 2012). Considering the very low access to electricity, natural ventilation is the major ventilation/cooling method in the majority of buildings.

Natural ventilation can provide thermal comfort; however, to provide effective natural ventilation, it is important to minimise 
internal and external heat gains (Wood and Salib, 2013). Solar heat gain is identified as one of the main contributors to overheating in residential buildings. Therefore, minimising solar heat gain can improve the effectiveness of natural ventilation. Solar heat gain can be controlled by reducing solar transmittance through windows, improving construction details/types to minimise surface heat transfer (Oughton and Wilson, 2015) and introducing shading to minimise solar transmission and heat gains through glazed and opaque surfaces (Brunoro, 2007). Solar transmittance, which is usually measured by using the $g$-value and solar heat gain coefficient, is highly affected by glass types (Thorpe, 2011). Due to possible high costs and limited access to different glazing types for low-income people, changing the glazing may not be an appropriate strategy to control solar heat gain in low-income housing.

Solar shading, in contrast, could be an appropriate strategy which could be considered to improve thermal comfort in low-income housing. Solar shading can be provided by means of internal and external shades. Generally, compared to internal shadings, external shadings are up to $30 \%$ more effective in minimising solar heat gain. For south- and north-facing windows, it is generally recommended to use horizontal external shading, while for east- and west-facing windows, application of vertical shading is recommended. Although more effective, external shading tends to be more expensive compared with internal shading (Cellai et al., 2014). This may arguably limit the applicability of external shades in low-income housing.

Yet the results of the study by Rockwood et al. (2015) suggest that shading is one of the key design features which may be considered to provide comfort in tropical affordable housing. A comparison between rooms with and without external solar shading showed that the risk of thermal discomfort in rooms with shaded windows reduced by up to $31 \%$ (Rockwood et al., 2015). A study by Yao (2013) showed that introducing moveable shading devices can help improve occupants' thermal comfort by 21 and $80 \%$ during summer and winter, respectively.

Becerra-Santacruz et al. (2018) carried out post-occupancy evaluations in low-income houses built with industrialised building methods in Mexico and found that overheating could be a major issue in these houses. Some argue that global warming may make overheating a major issue even in countries with more moderate climates (Rodrigues and Gillott, 2013). Kinnane et al. (2017) claim that due to climate change, there may be a need for mechanical ventilation in homes built for older people in the UK. According to Lau et al. (2016), applying different solar shading configurations would reduce the cooling demand by up to $10 \%$. Considering direct correlation between cooling demand and occupants' thermal comfort, it could be argued that solar shading would also improve thermal comfort in naturally ventilated buildings. Other studies suggest that adaptive behaviours of occupants of naturally ventilated buildings should be considered when evaluating thermal comfort in buildings. Gou et al. (2018)

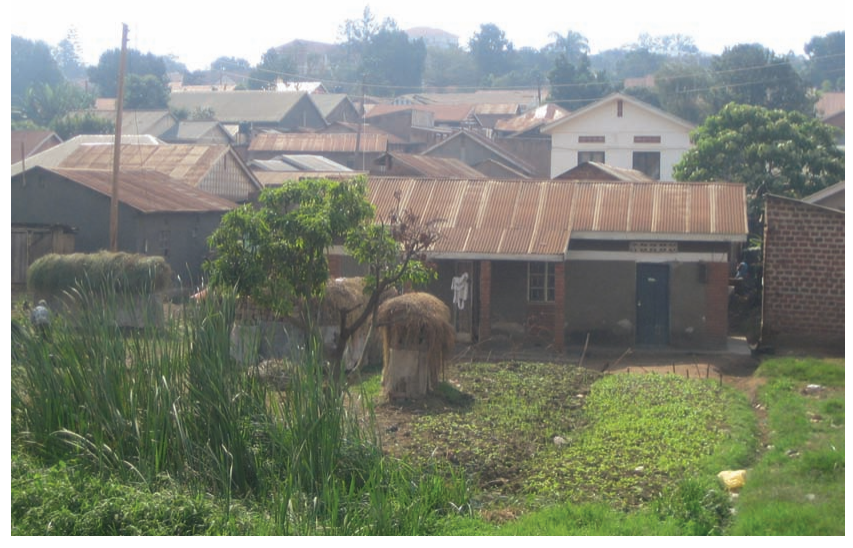

Figure 1. Low-income housing

argue that adaptive behaviour significantly improves thermal comfort in natural ventilated buildings in tropical climates.

This study evaluates the effects of solar shading strategies on the risk of overheating and thermal discomfort in low-income tropical houses in Uganda (Figure 1). The paper is an output of an Engineering and Physical Sciences Research Council-funded research programme, namely, 'Energy and Low-income Tropical Housing', that intends to identify and develop methods of reducing the energy consumption of low-income housing in tropical countries. The effects of alternative construction methods and materials and refurbishment strategies on thermal comfort as well as embodied energy and environmental impacts of construction methods and materials have been reported in other papers (Hashemi, 2016; Hashemi et al., 2015a, 2015b).

\section{Methodology}

Dynamic thermal simulations (DTSs) were conducted using EnergyPlus software to evaluate the effects of various shading strategies on solar heat gain and thermal comfort in a typical low-income house in Uganda. The test reference year for Kisumu in Kenya was chosen as the closest available weather data to Kampala, as there are no available weather data for thermal simulations in Uganda. Kampala and Kisumu are located on the northern coast of Lake Victoria and have similar altitudes above sea level. It should be noted that this is a comparative study of different shading strategies in low-income housing in the region, despite possible minor differences between the climatic conditions of Kampala and Kisumu.

Considering that over $50 \%$ of Ugandan families live in singleroomed homes with an average household size of 3.9 people in urban areas (Ubos, 2010), a single-zone $3 \times 3 \times 3 \mathrm{~m}$ building with four occupants was modelled. A south-facing window $(1 \times 1 \mathrm{~m})$ and door $(2 \times 1 \mathrm{~m})$ with an effective opening area of $80 \%$ were also considered. Permanent background ventilators 
Assessment of solar shading strategies in low-income tropical housing: the case of Uganda

Hashemi

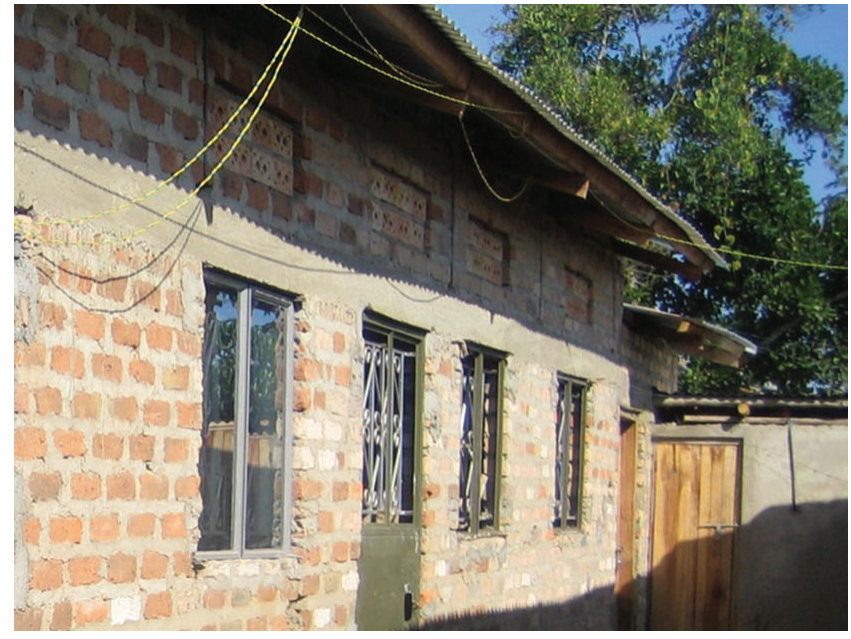

Figure 2. Permanent ventilators on windows and doors

were introduced above the window and door as a common practice in Uganda (Figure 2).

'AirflowNetwork' in EnergyPlus was used to simulate accurately natural ventilation and air infiltration through the openings and cracks in the walls. A constant 'ventilation control mode' was considered for controlling the windows and doors. An 'air mass flow exponent' of 0.66 was introduced for the cracks and trickle vents, and a discharge coefficient of 0.6 was used for the open doors and windows (Cibse, 2015).

According to the available data, brick walls (57\%) and iron sheet roofs $(62 \%)$ are the prevailing walling and roofing methods/ materials in Uganda. Cement/concert flooring (70\%) is also the most common flooring material in urban areas of the country (NPA, 2010; Ubos, 2010). Simulations were therefore conducted for the most common construction methods. Table 1 summarises the properties of the materials based on the available information in the report by Perez (2009) and CIBSE Guide A (Cibse, 2015).

The occupancy profile in the case study building was specified as fully occupied between 6 p.m. and 8 a.m. and one occupant between 8 a.m. and 6 p.m. The window and door were assumed to be open between $6.30 \mathrm{a} . \mathrm{m}$. and $6.30 \mathrm{p} . \mathrm{m}$. and between 7 a.m. and 8 p.m., respectively (Olweny, 1996). For the purpose of this study, 33 different combination scenarios were simulated. The effects of various internal and external shading strategies including curtains, roof and window overhangs, veranda and trees as well as white paint (to reduce solar absorptance) on solar heat gain and thermal comfort were investigated (Table 2). Figure 3 illustrates the simplified geometries of the simulated buildings in EnergyPlus.

The performance of the proposed options was studied by reporting solar heat gain and risk of overheating. An adaptive approach was used to assess thermal comfort conditions. Due to the lack of national standards/regulations, the European Committee for Standardization (CEN) standard BS EN 15251:2007 (BSI, 2007) was used to evaluate thermal comfort conditions. Thermal comfort in the adaptive approach is affected by occupants' behaviours and expectations in naturally ventilated buildings (Djongyang et al., 2010). Based on this method of evaluation, it is proposed that occupants' perception regarding thermal comfort is affected by their past thermal history (De Dear and Brager, 1998). For typical occupants, the CEN standard BS EN 15251:2007 suggests the following equation to estimate comfortable temperature in naturally ventilated buildings

\section{1. $T_{\text {comf }}=0 \cdot 33 T_{\mathrm{rm}}+18 \cdot 8+3 \quad\left(\right.$ where $\left.T_{\mathrm{rm}}>10^{\circ} \mathrm{C}\right)$}

Table 2. Tested scenarios

\begin{tabular}{|c|c|c|c|}
\hline \multirow{2}{*}{$\begin{array}{l}\text { Shading option } \\
\text { Curtains }\end{array}$} & \multicolumn{3}{|r|}{ Conditions } \\
\hline & None & $\begin{array}{l}\text { Always } \\
\text { on }\end{array}$ & $\begin{array}{l}\text { On if beam plus diffuse } \\
\text { solar radiation incident } \\
\text { on the window exceeds } \\
50 \mathrm{~W} / \mathrm{m}^{2}\end{array}$ \\
\hline Roof overhangs & None & $\begin{array}{l}0.5 \mathrm{~m} \\
\text { both } \\
\text { sides }\end{array}$ & $\begin{array}{l}\text { Veranda: } 2 \mathrm{~m} \text { shade on } \\
\text { south and } 0.5 \mathrm{~m} \text { roof } \\
\text { shade on north }\end{array}$ \\
\hline $\begin{array}{l}\text { External horizontal } \\
\text { shade on windows } \\
\text { (window overhang) }\end{array}$ & None & $0.5 \mathrm{~m}$ & - \\
\hline Trees & None & \multicolumn{2}{|c|}{$\begin{array}{l}\text { Two triangular trees, one south and } \\
\text { one north ( } 12 \mathrm{~m} \text { high, } 6 \mathrm{~m} \text { wide, } \\
6 \mathrm{~m} \text { away from the building) }\end{array}$} \\
\hline White paint & None & \multicolumn{2}{|c|}{$\begin{array}{l}\text { Painted roof, painted walls, } \\
\text { painted walls and roof }\end{array}$} \\
\hline
\end{tabular}

Table 1. Material properties used in the simulations

\begin{tabular}{|c|c|c|c|c|c|}
\hline Material & $\begin{array}{l}\text { Thermal conductivity: } \\
\qquad \mathrm{W} /(\mathrm{m} \mathrm{K})\end{array}$ & Thickness: m & Density: $\mathrm{kg} / \mathrm{m}^{3}$ & $\begin{array}{c}\text { Solar } \\
\text { transmittance }\end{array}$ & $\begin{array}{c}\text { Solar } \\
\text { absorptance }\end{array}$ \\
\hline Brick wall & $1 \cdot 0$ & $0 \cdot 200$ & 1900 & - & $0 \cdot 70$ \\
\hline White-painted brick wall & $1 \cdot 0$ & 0.200 & 1900 & - & 0.20 \\
\hline Iron sheet roof & $37 \cdot 0$ & 0.003 & 7800 & - & $0 \cdot 70$ \\
\hline White-painted iron sheet roof & $37 \cdot 0$ & 0.003 & 7800 & - & 0.20 \\
\hline Concrete & $1 \cdot 31$ & $0 \cdot 100$ & 2240 & - & 0.70 \\
\hline Glass & 0.90 & 0.006 & - & 0.775 & - \\
\hline
\end{tabular}




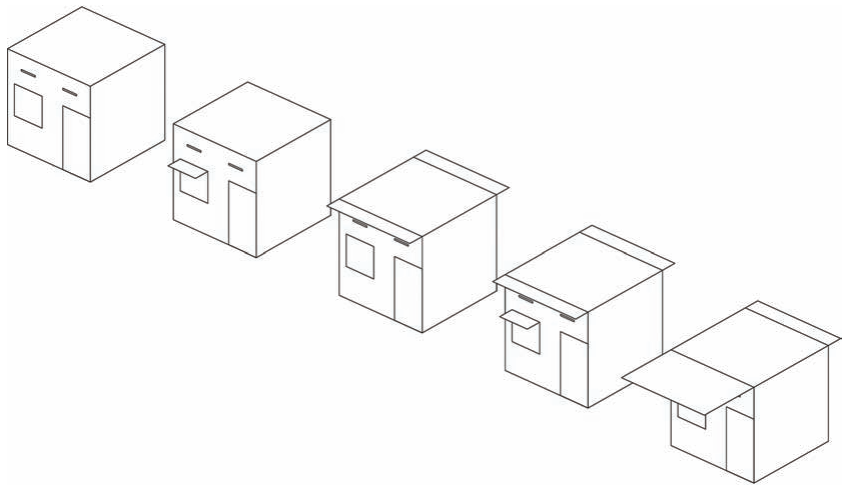

Figure 3. Simplified geometries of the simulated buildings. From left to right: the base case, window overhang, roof overhang, roof and window overhang, veranda

where $T_{\text {comf }}$ is the maximum comfortable temperature $\left({ }^{\circ} \mathrm{C}\right)$ and $T_{\mathrm{rm}}$ is the running mean temperature for today weighted with the higher influence of recent days $\left({ }^{\circ} \mathrm{C}\right)$ (Nicol and Humphreys, 2010).

$T_{\mathrm{rm}}$ can be calculated using the equation

2. $T_{\mathrm{rm}}=(1-\alpha)\left(T_{\text {ed-1 }}+\alpha T_{\text {ed-2 }}+\alpha^{2} T_{\text {ed-3 }}+\cdots\right)$

where $T_{\text {ed-1 }}$ is the daily mean external temperature for the previous day $\left({ }^{\circ} \mathrm{C}\right), T_{\text {ed-2 }}$ is the daily mean external temperature for the day before the previous day $\left({ }^{\circ} \mathrm{C}\right)$ and so on and $\alpha$ is a constant. Tuohy et al. (2009) suggest to use $0 \cdot 8$ for $\alpha$.

In the adaptive method, the risk of overheating is assessed based on the frequency and severity of overheating. The risk of overheating in a room is evaluated by using three different criteria. A building is assumed to be overheated if it fails any two of the three adaptive assessment criteria. All three criteria are defined in terms of $\Delta T$, which is the difference between the operative temperature and the maximum acceptable temperature (Table 3). The operative temperature articulates the joint effect of

Table 3. Assessment criteria for studying the risk of overheating in naturally ventilated buildings

\begin{tabular}{|c|c|c|}
\hline \multicolumn{2}{|c|}{ Assessment criterion } & \multirow{2}{*}{$\begin{array}{l}\text { Acceptable } \\
\text { deviation } \\
\text { Up to } 3 \% \text { of } \\
\text { occupied } \\
\text { hours }\end{array}$} \\
\hline Criterion 1 & $\begin{array}{l}\text { Frequency of occupied hours when } \\
\text { the operative temperature is } \\
\text { greater than the maximum } \\
\text { comfortable temperature }\end{array}$ & \\
\hline Criterion 2 & $\begin{array}{l}\text { Severity of thermal discomfort; } \\
\text { calculated as number of day } \\
\text { degree hours of warm period } \\
>6 \text { degree-hours a day }\end{array}$ & $0 d$ \\
\hline Criterion 3 & $\begin{array}{l}\text { Severity of thermal discomfort; } \\
\text { reported as number of hours in } \\
\text { which } \Delta T>4 \mathrm{~K}\end{array}$ & $\mathrm{Oh}$ \\
\hline
\end{tabular}

air temperature and mean radiant temperature along with the internal air movement as a single figure. For an indoor air speed less than $0.1 \mathrm{~m} / \mathrm{s}$, the operative temperature $\left(T_{\mathrm{op}}\right)$ could be calculated from the following equation (Cibse, 2013)

3. $T_{\text {op }}=\left(T_{\mathrm{a}}+T_{\mathrm{r}}\right) / 2$

where $T_{\mathrm{a}}$ is the air temperature $\left({ }^{\circ} \mathrm{C}\right)$ and $T_{\mathrm{r}}$ is the mean radiant temperature $\left({ }^{\circ} \mathrm{C}\right)$.

\section{Results}

Tables 4-10 summarise the results of the simulations for all 33 combination scenarios. The results have been divided into five geometry categories and six schedule categories as follows. The effects of including/excluding trees and curtains have been evaluated for each geometry condition. The effects of white paint are assessed in category $(c)$ for the main base case only (brick walls without any shading)

(a) geometry categories
(i) base case
(ii) window shade/overhang
(iii) roof shade/overhang
(iv) roof + window shade/overhang
(v) veranda

Table 4. Thermal comfort criteria for schedule 1: curtain off - no trees

\begin{tabular}{|c|c|c|c|c|}
\hline ID & Geometry & $\begin{array}{c}\text { Criterion } \\
1: \%\end{array}$ & $\begin{array}{c}\text { Criterion } 2 \\
\text { (daily degree- } \\
\text { hours over 6) }\end{array}$ & $\begin{array}{c}\text { Criterion } 3 \\
\text { ( } \Delta T \text { over } \\
4 \mathrm{~K})\end{array}$ \\
\hline 1 & Main base case & $13 \cdot 40$ & 134 & 21 \\
\hline 2 & $\begin{array}{l}\text { Window } \\
\text { shade/overhang }\end{array}$ & 13.03 & 132 & 15 \\
\hline 3 & $\begin{array}{l}\text { Roof } \\
\text { shade/overhang }\end{array}$ & $12 \cdot 76$ & 128 & 14 \\
\hline 4 & $\begin{array}{l}\text { Roof + window } \\
\text { shade/overhang }\end{array}$ & $12 \cdot 47$ & 123 & 12 \\
\hline 5 & Veranda & $12 \cdot 38$ & 124 & 11 \\
\hline
\end{tabular}

Table 5. Thermal comfort criteria for schedule 2: curtain off trees to the north and south

\begin{tabular}{|c|c|c|c|c|}
\hline ID & Geometry & $\begin{array}{c}\text { Criterion } \\
\text { 1: } \%\end{array}$ & $\begin{array}{c}\text { Criterion } 2 \\
\text { (daily degree- } \\
\text { hours over 6) }\end{array}$ & $\begin{array}{c}\text { Criterion } 3 \\
(\Delta T \text { over } \\
4 \mathrm{~K})\end{array}$ \\
\hline 6 & Base case & 13.07 & 130 & 20 \\
\hline 7 & $\begin{array}{l}\text { Window } \\
\text { shade/overhang }\end{array}$ & $12 \cdot 64$ & 124 & 12 \\
\hline 8 & $\begin{array}{l}\text { Roof } \\
\text { shade/overhang }\end{array}$ & $12 \cdot 35$ & 120 & 12 \\
\hline 9 & $\begin{array}{l}\text { Roof + window } \\
\text { shade/overhang }\end{array}$ & $12 \cdot 13$ & 118 & 11 \\
\hline 10 & Veranda & $12 \cdot 15$ & 121 & 11 \\
\hline
\end{tabular}


Table 6. Thermal comfort criteria for schedule 3: curtain on - no trees

\begin{tabular}{|c|c|c|c|c|}
\hline ID & Geometry & $\begin{array}{c}\text { Criterion } \\
\text { 1: \% }\end{array}$ & $\begin{array}{c}\text { Criterion } 2 \\
\text { (daily degree- } \\
\text { hours over } 6 \text { ) }\end{array}$ & $\begin{array}{c}\text { Criterion } 3 \\
(\Delta T \text { over } \\
4 \mathrm{~K})\end{array}$ \\
\hline 11 & Base case & $13 \cdot 10$ & 132 & 18 \\
\hline 12 & $\begin{array}{l}\text { Window } \\
\text { shade/overhang }\end{array}$ & $12 \cdot 94$ & 129 & 13 \\
\hline 13 & $\begin{array}{l}\text { Roof } \\
\text { shade/overhang }\end{array}$ & $12 \cdot 51$ & 125 & 13 \\
\hline 14 & $\begin{array}{l}\text { Roof + window } \\
\text { shade/overhang }\end{array}$ & $12 \cdot 39$ & 123 & 11 \\
\hline 15 & Veranda & $12 \cdot 23$ & 122 & 11 \\
\hline
\end{tabular}

Table 7. Thermal comfort criterion for schedule 4: curtain on trees to the north and south

\begin{tabular}{|c|c|c|c|c|}
\hline ID & Geometry & $\begin{array}{c}\text { Criterion } \\
\text { 1: } \%\end{array}$ & $\begin{array}{c}\text { Criterion } 2 \\
\text { (daily degree- } \\
\text { hours over } 6 \text { ) }\end{array}$ & $\begin{array}{c}\text { Criterion } 3 \\
(\Delta T \text { over } \\
4 \mathrm{~K})\end{array}$ \\
\hline 16 & Base case & $12 \cdot 81$ & 126 & 13 \\
\hline 17 & $\begin{array}{l}\text { Window } \\
\text { shade/overhang }\end{array}$ & $12 \cdot 52$ & 123 & 12 \\
\hline 18 & $\begin{array}{l}\text { Roof } \\
\text { shade/overhang }\end{array}$ & $12 \cdot 20$ & 118 & 11 \\
\hline 19 & $\begin{array}{l}\text { Roof + window } \\
\text { shade/overhang }\end{array}$ & 11.98 & 117 & 11 \\
\hline 20 & Veranda & $12 \cdot 08$ & 118 & 10 \\
\hline
\end{tabular}

Table 8. Thermal comfort criteria for schedule 5: curtain on if beam plus diffuse solar radiation incident on the window exceeds $50 \mathrm{~W} / \mathrm{m}^{2}-$ no trees

\begin{tabular}{|c|c|c|c|c|}
\hline ID & Geometry & $\begin{array}{c}\text { Criterion } \\
\text { 1: } \%\end{array}$ & $\begin{array}{c}\text { Criterion } 2 \\
\text { (daily degree- } \\
\text { hours over 6) }\end{array}$ & $\begin{array}{c}\text { Criterion } 3 \\
(\Delta T \text { over } \\
4 \mathrm{~K})\end{array}$ \\
\hline 21 & Base case & 13.09 & 132 & 18 \\
\hline 22 & $\begin{array}{l}\text { Window } \\
\text { shade/overhang }\end{array}$ & $12 \cdot 93$ & 129 & 13 \\
\hline 23 & $\begin{array}{l}\text { Roof } \\
\text { shade/overhang }\end{array}$ & $12 \cdot 50$ & 125 & 13 \\
\hline 24 & $\begin{array}{l}\text { Roof }+ \text { window } \\
\text { shade/overhang }\end{array}$ & $12 \cdot 37$ & 122 & 11 \\
\hline 25 & Veranda & $12 \cdot 22$ & 122 & 11 \\
\hline
\end{tabular}

Table 9. Thermal comfort criteria for schedule 6: curtain on if beam plus diffuse solar radiation incident on the window exceeds $50 \mathrm{~W} / \mathrm{m}^{2}$ - trees to the north and south

\begin{tabular}{|c|c|c|c|c|}
\hline ID & Geometry & $\begin{array}{c}\text { Criterion } \\
\text { 1: } \%\end{array}$ & $\begin{array}{c}\text { Criterion } 2 \\
\text { (daily degree- } \\
\text { hours over } 6 \text { ) }\end{array}$ & $\begin{array}{c}\text { Criterion } 3 \\
(\Delta T \text { over } \\
4 \mathrm{~K})\end{array}$ \\
\hline 26 & Base case & $12 \cdot 79$ & 126 & 13 \\
\hline 27 & $\begin{array}{l}\text { Window } \\
\text { shade/overhang }\end{array}$ & $12 \cdot 52$ & 123 & 12 \\
\hline 28 & $\begin{array}{l}\text { Roof } \\
\text { shade/overhang }\end{array}$ & $12 \cdot 19$ & 118 & 11 \\
\hline 29 & $\begin{array}{l}\text { Roof + window } \\
\text { shade/overhang }\end{array}$ & 11.95 & 117 & 11 \\
\hline 30 & Veranda & $12 \cdot 04$ & 117 & 10 \\
\hline
\end{tabular}

Table 10. Thermal comfort criteria for schedule 7: white-painted roof and walls for the base case

\begin{tabular}{|cccc|}
\hline ID $\quad$ Geometry & $\begin{array}{c}\text { Criterion } \\
\text { 1: \% }\end{array}$ & $\begin{array}{c}\text { Criterion 2 } \\
\text { (daily degree- } \\
\text { hours over 6) }\end{array}$ & $\begin{array}{c}\text { Criterion } 3 \\
(\Delta T \text { over } \\
\mathbf{4} \text { K) }\end{array}$ \\
\hline $31 \quad \begin{array}{l}\text { White-painted } \\
\text { roof }\end{array}$ & $6 \cdot 8$ & 44 & 2 \\
$32 \begin{array}{c}\text { White-painted } \\
\text { walls }\end{array}$ & 7.5 & 52 & 2 \\
$33 \begin{array}{l}\text { White-painted } \\
\text { roof and walls }\end{array}$ & 0.2 & 0 & 0 \\
\hline
\end{tabular}

(b) schedule categories

(i) curtain off - no trees

(ii) curtain off - trees to the north and south

(iii) curtain on - no trees

(iv) curtain on - trees to the north and south

(v) curtain on if beam plus diffuse solar radiation incident on the window exceeds $50 \mathrm{~W} / \mathrm{m}^{2}$ - no trees

(vi) curtain on if beam plus diffuse solar radiation incident on the window exceeds $50 \mathrm{~W} / \mathrm{m}^{2}$ - trees to the north and south

(c) paint categories

(i) white-painted roof

(ii) white-painted walls

(iii) white-painted walls and roof.

According to the results, none of the tested combination scenarios for solar shading (categories $(a)$ and (b); IDs 1-30; Tables 4-9) met thermal comfort requirements. However, compared to the base case, comfort conditions improved when solar shading was introduced. The best conditions were achieved when a veranda with a $2 \mathrm{~m}$ projected roof (supported by columns) was considered (ID 30). Shading strategies seemed to be most effective during the hottest periods of the year when criterion $3(\Delta T$ over $4 \mathrm{~K}$ ) was more likely to fail. Indeed, the geometry shading strategies (category $(a)$ ) had marginal effects on criteria 1 and 2 of TM52 thermal comfort criteria (Table 4).

For schedule 1 (curtain off - no trees), compared to the base case (ID 1), the risk of extreme overheating for criterion 3 reduced from 21 to 11 incidents $(47 \cdot 6 \%)$ when a veranda was used. The risk of overheating considerably reduced for the other methods too. A performance similar to that for a veranda (ID 5) was achieved when roof and window overhangs were jointly considered (ID 4).

For schedule 2, when trees were introduced (Table 5), compared to the base case (ID 6), all shading strategies achieved a similar performance reducing the risk of extreme overheating by more than $40 \%$ (IDs 7-10). However; the situation for the base case in 
schedule 2 (ID 6) was only marginally improved compared to the main base case in schedule 1 (Table 4).

Including curtains in schedule 3 (Table 6) slightly improved thermal comfort conditions. Comparing schedule 2 with schedule 3 , curtains have been slightly more effective in achieving better conditions during extremely hot days (criterion 3), while trees performed slightly better than curtains for criterion 2 .

The results reveal that schedules 3 and 5 and schedules 4 and 6 have almost identical performances, meaning that the 'beam' plus 'diffuse' solar radiation incident on the window always exceeded $50 \mathrm{~W} / \mathrm{m}^{2}$, which means that the curtains were almost always on (refer to Table 2). Overall, as expected, the best conditions were achieved when trees and curtains were considered together (schedules 4 and 6; IDs 19, 20, 29 and 30). Compared to the main base case (ID 1), there were around 10, 13 and 50\% improvements on criteria 1,2 and 3, respectively. Yet such improvements were not enough to meet the comfort requirements.

Further investigation was carried out to evaluate the effects of reducing solar absorptance properties of the roof and walls by applying white paint. According to the results, unlike solar shading, white paint was considerably effective in reducing the risk of overheating (Table 10). However, although thermal comfort improved, a white-painted roof and white-painted walls failed two of the three thermal comfort criteria, meaning that overall they failed to meet the requirements. The risk of overheating was decreased significantly when both walls and roof were painted. Indeed, white-painted roof and walls passed all three requirements. ID 33 was therefore the only scenario which achieved the required standards.

Figure 4 compares the operative temperature for the main base case (ID 1: iron roof, concrete floor, bare brick walls) and the best-case scenarios (ID 33: white-painted walls and roof) during the year. As shown, the operative temperature for ID 33 is considerably more stable and is almost always below the maximum comfortable temperature $\left(T_{\max }\right)$. Unlike ID 33 , the operative temperature for the base case frequently goes above the maximum comfortable temperature and occasionally reaches the upper limit temperature $\left(T_{\text {upp }}\right)$, which is an indicator of the severity of thermal discomfort.

\section{Discussion}

According to the results of this study, although solar shading reduces the risk of overheating, shading strategies are less effective in achieving thermal comfort requirements on their own. Therefore, solar shading should be used in conjunction with other strategies in order to meet thermal comfort criteria. Nevertheless, excessive solar heat gain has been identified as one of the major contributors to overheating in buildings. Solar gain can be controlled by introducing shading to minimise solar transmission and heat gains through glazed and opaque surfaces (Brunoro, 2007).

Figure 5 shows the sun path diagram during the winter and summer in Kampala. According to this figure, the sun falls on the

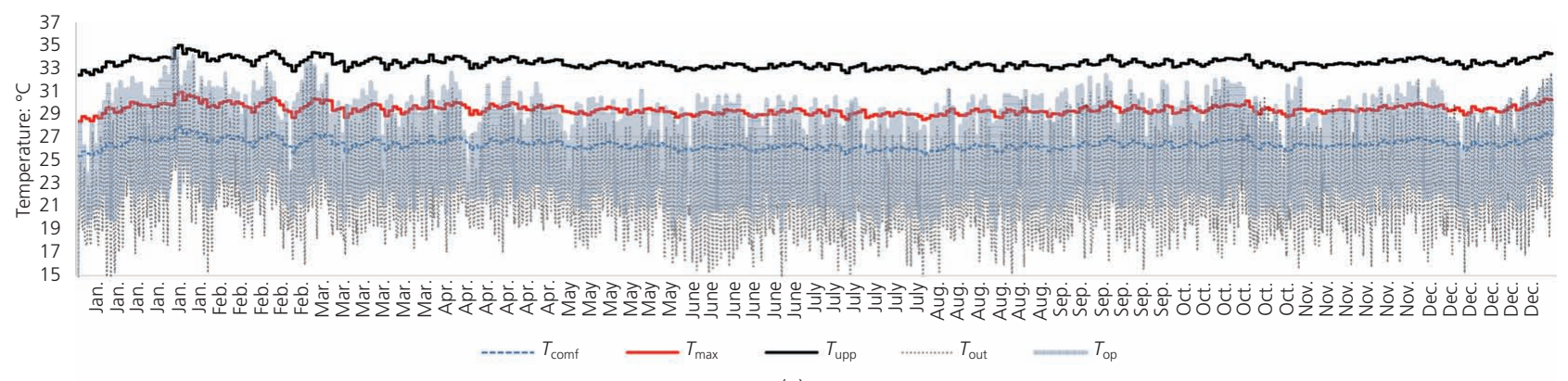

(a)

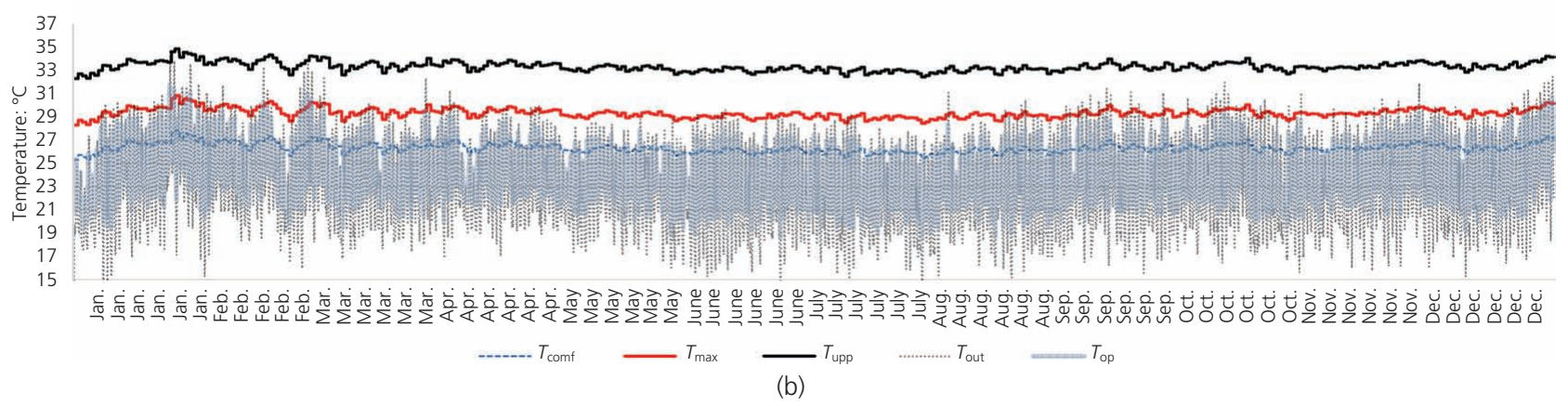

Figure 4. Thermal comfort conditions for (a) the base case (ID 1: iron roof, concrete floor, bare brick walls) and (b) the best-case scenario (ID 33: white-painted roof and walls). A full-colour version of this figure can be found on the ICE Virtual Library (www.icevirtuallibrary.com) 
Assessment of solar shading strategies in low-income tropical housing: the case of Uganda

Hashemi

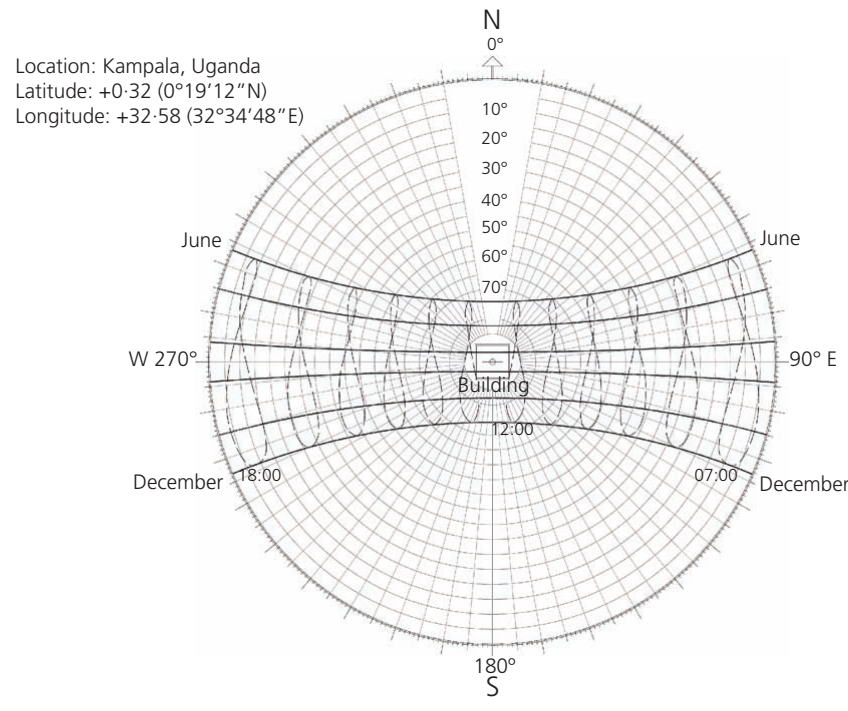

Figure 5. Sun path diagram - Kampala, Uganda

south elevation during the hottest summer periods during December and February. Therefore, it could be argued that significant solar transmittance may occur during the hottest period of the year from windows and other openings on the south elevation.

Table 11 summarises the average transmitted solar radiation rate for the window over the entire year (total transmitted solar radiation rate/365) for 30 different tested scenarios. The transmitted solar radiation rate, according to EnergyPlus, is the sum of the transmitted 'beam solar radiation rate' and 'diffuse solar radiation rate' through the window (US DOE, 2016). The average diffuse and direct solar radiation rates per area for the site are also reported in Table 11. It is evident that, apart from trees, all shading strategies have significantly reduced the transmitted solar radiation through the window. A possible explanation for this is that unlike 'attached shadings surfaces', such as overhangs, trees have not been able to provide effective shading over the windows. The most effective condition was achieved when curtains were combined with window and roof overhangs. Transmitted solar radiation, in this scenario, has decreased from $57.06 \mathrm{~W}$ (the base case without any shading) to $13.42 \mathrm{~W}$, which means a reduction of around $76 \%$.

Overall, the findings reveal that solar shading is very effective in reducing solar heat gain through windows. However, due to the relatively small size of the windows in the case study buildings and considerably higher solar heat gain through other building elements, such as the roof, window shading/overhang did not make a meaningful difference in terms of total solar heat gain and thermal comfort. Shading, however, could significantly improve the conditions by reducing excessive solar heat gain through large openings. It should be noted that small openings may also be in contrast with natural ventilation strategies which could provide better comfort conditions. The effects of ventilation strategies on thermal comfort in low-income tropical housing need further investigation.

Moreover, according to Figure 5, the sun has a very high altitude in Kampala during the entire year. This indicates that the roof is receiving the highest solar heat gain compared to other building elements, implying the importance of the roof as a major contributor to risk of overheating in tropical climates. The high sun altitude also indicates that, unless planted very close to the building, trees may be less effective in providing effective shading over the buildings; however, the microclimatic effects of plants and trees may improve the conditions. Such effects of trees and plants on thermal comfort in tropical climates were not the focus of this study and should be investigated in detail.

Figure 6 shows the average annual solar radiation heat gain rate per area $\left(\mathrm{W} / \mathrm{m}^{2}\right)$ for the building envelope in the base case where no shading was considered. The results reveal that solar heat gain of the roof is over 2.5 times higher than that of north- and southfacing walls. During February, the average monthly heat gain from the roof has been four times more than that from any walls. The roof construction/material is therefore a key factor affecting thermal comfort in tropical climates. Other studies also support this finding, identifying the roof as a key factor in reducing

Table 11. The average transmitted solar radiation rate through the window: W

\begin{tabular}{|c|c|c|c|c|c|}
\hline & $\begin{array}{l}\text { Base } \\
\text { case }\end{array}$ & $\begin{array}{l}\text { Window shade/ } \\
\text { overhang }\end{array}$ & $\begin{array}{l}\text { Roof shade/ } \\
\text { overhang }\end{array}$ & $\begin{array}{l}\text { Roof + window } \\
\text { shade/overhang }\end{array}$ & Veranda \\
\hline Curtain off - no trees & 57.06 & $41 \cdot 24$ & $52 \cdot 89$ & $40 \cdot 88$ & $42 \cdot 29$ \\
\hline Curtain off - trees to the north and south & 54.08 & $38 \cdot 84$ & $49 \cdot 75$ & 38.48 & $39 \cdot 84$ \\
\hline Curtain on - no trees & $18 \cdot 3$ & $13 \cdot 22$ & $16 \cdot 96$ & $13 \cdot 11$ & $13 \cdot 56$ \\
\hline Curtain on - trees to the north and south & $17 \cdot 34$ & $12 \cdot 45$ & $15 \cdot 95$ & $12 \cdot 34$ & $12 \cdot 77$ \\
\hline $\begin{array}{l}\text { Curtain on if beam plus diffuse solar radiation } \\
\text { incident on the window exceeds } 50 \mathrm{~W} / \mathrm{m}^{2}- \\
\text { no trees }\end{array}$ & $19 \cdot 1$ & $14 \cdot 18$ & $17 \cdot 77$ & 14.06 & $14 \cdot 48$ \\
\hline $\begin{array}{l}\text { Curtain on if beam plus diffuse solar radiation } \\
\text { incident on the window exceeds } 50 \mathrm{~W} / \mathrm{m}^{2}- \\
\text { trees to the north and south }\end{array}$ & $18 \cdot 23$ & $13 \cdot 54$ & $16 \cdot 9$ & $13 \cdot 42$ & $13 \cdot 79$ \\
\hline \multicolumn{6}{|c|}{ Average site diffuse solar radiation rate: $178.56 \mathrm{~W} / \mathrm{m}^{2}$} \\
\hline Average site direct solar radiation rate: 103.34 & & & & & \\
\hline
\end{tabular}




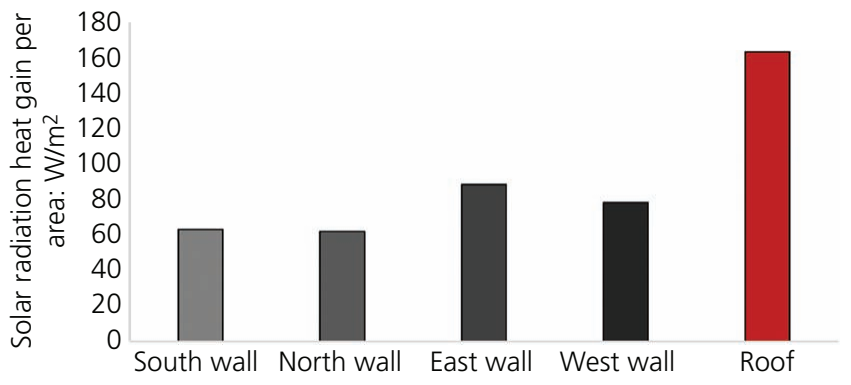

Figure 6. Solar radiation heat gain for the base case without shading

or increasing the risk of overheating and thermal discomfort in low-income tropical housing (Hashemi, 2016; Hashemi et al., 2015a). This also explains the considerable improvement in thermal comfort conditions when the roof was painted (ID 31).

The results also reveal that the average solar heat gain from eastand west-facing walls and windows is up to 1.4 times higher than that from walls and windows facing north and south. Similar to the roof, painting the walls with white paint (ID 32) significantly reduced the solar absorptance of the walls and therefore improved the conditions. It should be noted, however, that dirt, dust and rust could neutralise the effects of white paint, increasing the solar absorptance properties of the walls and roof, resulting in thermal discomfort. Furthermore, considering the relatively high solar gain of east- and west-facing walls, building layout and orientation are critical. In this respect, a north-south orientation with main openings on the north elevation is recommended. Large openings should also be avoided on east- and west-facing walls.

\section{Conclusions}

This study investigated the effects of shading strategies including curtains, roof and window overhangs, veranda and trees on solar heat gain and thermal comfort in low-income tropical houses in Uganda. Effects of solar gain and white painting on walls and the roof were also investigated. DTSs were conducted for buildings with brick walls and iron sheet roof as the most common construction method in urban areas of Uganda. According to the results, although introducing solar shading improved thermal comfort conditions, none of the tested shading scenarios was effective enough to meet thermal comfort requirements. Shading strategies appeared to be most effective during the hottest periods of the year, reducing the risk of extreme overheating (criterion 3 of the assessment criteria) by over $50 \%$.

The average solar heat gain from the east- and west-facing walls and windows was up to 1.4 times higher than that from walls and windows facing north and south. A north-south building orientation with the main openings on the north side is therefore recommended as the most appropriate building layout/orientation to reduce the risk of overheating and thermal discomfort in the tropical climate of Kampala. Moreover, large openings on east- and west-facing walls should be avoided. Furthermore, the average solar gain of the roof during the hottest periods of the year was up to four times higher than that of north- and southfacing walls. White painting proved to be an effective strategy to improve the conditions by reducing the 'solar absorptance' of the walls and roof. White-painted roofs and walls are therefore recommended to reduce the risk of overheating and thermal discomfort in the tropical climate of Kampala.

This study focused on the effects of solar shading on thermal comfort. Further research is required to evaluate the effects of other types of shading as well as natural ventilations strategies and microclimatic effects of trees/plants on thermal comfort in tropical climates.

\section{The practical relevance and potential applications of the work}

Developing countries in tropical and subtropical areas will be the worst hit by climate change. Due to limited access to resources, climate adaptation in the poorest countries is left to individuals as a matter of 'self-help'. This situation puts low-income populations in a more vulnerable position, as they have even less access to resources to adapt to climate change. This paper intends to assist low-income populations by developing simple strategies to improve thermal comfort in their homes.

\section{Acknowledgements}

This document is an output from the research project 'Energy and Low-income Tropical Housing' co-funded by UK aid from the UK Department for International Development (DFID), the Engineering and Physical Sciences Research Council (EPSRC) and the Department for Energy and Climate Change (DECC), for the benefit of developing countries (Ref. EP/L002604/1). The views expressed are not necessarily those of DFID, EPSRC or DECC. Special thanks are given to Heather Cruickshank for the pictures.

\section{REFERENCES}

Actwatch Group and Pace (Programme for Accessible Health, Communication and Education) Uganda (2013) Household Survey, Uganda, 2012 Survey Report. Population Services International, Washington, DC, USA.

Agra (Alliance for a Green Revolution in Africa) (2010) Baseline Survey, AGRA Interventions in Uganda, Final Report. Agra, Accra, Ghana.

Batchelder D, Caiola R and Davenport S (1985) Construction Reference Manual, a Source Book for the Use of Local Materials in Construction. The Experiment in International Living, Brattleboro, VT, USA.

Becerra-Santacruz H, Patlakas and Altan H (2018) Evaluation and visualisation of Mexican mass housing thermal performance. Proceedings of the Institution of Civil Engineers - Engineering Sustainability, https://doi.org/10.1680/jensu.16.00040.

Brunoro L (2007) Sustainable technologies in the refurbishment of existing building envelopes. In Portugal SB07 Sustainable Construction, Materials and Practices, Challenge of Industry for New Millennium, Part 1 (Braganca L, Pinheiro M, Jalali S et al. (eds)). IOS Press, Amsterdam, the Netherlands.

BSI (2007) BS EN 15251:2007: Indoor environmental input parameters for design and assessment of energy performance of buildings 
addressing indoor air quality, thermal environment, lighting and acoustics. BSI, London, UK.

Byakola T (2007) Improving Energy Resilience in Uganda. Helio International, Paris, France.

Cellai G, Carletti C, Sciurpi T and Secchi S (2014) Transparent building envelope: windows and shading devices typologies for energy efficiency refurbishments. In Building Refurbishment for Energy Performance: a Global Approach (Magrini A (ed.)). Springer, Cham, Switzerland, pp. 61-118.

Cibse (Chartered Institution of Building Services Engineers) (2013) CIBSE TM52 2013: The limits of thermal comfort: avoiding overheating in European buildings. Cibse, London, UK.

Cibse (2015) CIBSE Guide A: Environmental Design. Cibse, London, UK.

Craterre (International Centre for Earthen Architecture) (2005) Earth Architecture in Uganda, Pilot Project in Bushennyi 2002-2004. Craterre, Grenoble, France.

De Dear R and Brager GS (1998) Towards an adaptive model of thermal comfort and preference. ASHRAE Transactions 104(1): 145-167.

Djongyang N, Tchinda R and Njomo D (2010) Thermal comfort: a review paper. Renewable and Sustainable Energy Reviews 14(9): 2626-2640, https://doi.org/10.1016/j.rser.2010.07.040.

EMI (Engineering Ministries International) (2012) Architectural Design Guide. EMI - East Africa, Kampala, Uganda.

EPRC (Economic Policy Research Centre) (2013) Uganda 2013 FinScope III Survey Report Findings: Unlocking Barriers to Financial Inclusion. EPRC, Kampala, Uganda.

Gou Z, Gamage W, Lau SSY and Lau SSY (2018) An investigation of thermal comfort and adaptive behaviors in naturally ventilated residential buildings in tropical climates: a pilot study. Buildings 8(1): article 5, https://doi.org/10.3390/buildings8010005.

Hashemi A (2016) Climate resilient low-income tropical housing. Energies 9(6): article 468, https://doi.org/10.3390/en9060468

Hashemi A, Cruickshank and Cheshmehzangi A (2015a) Environmental impacts and embodied energy of construction methods and materials in low-income tropical housing. Sustainability 7(6): 7866-7883, https://doi.org/10.3390/su7067866.

Hashemi A, Cruickshank H and Cheshmehzangi A (2015b) Improving thermal comfort in low-income tropical housing: the case of Uganda. Proceedings of the ZEMCH 2015 International Conference, Lecce, Italy, pp. 613-622.

Kinnane O, Grey T and Dyer M (2017) Adaptable housing design for climate change adaptation. Proceedings of the Institution of Civil Engineers - Engineering Sustainability 170(5): 249-267, https://doi. org/10.1680/jensu. 15.00029

Lau AKK, Salleh E, Lim CH and Sulaiman MY (2016) Potential of shading devices and glazing configurations on cooling energy savings for highrise office buildings in hot-humid climates: the case of Malaysia. International Journal of Sustainable Built Environment 5(2): 387-399, https://doi.org/10.1016/j.ijsbe.2016.04.004.

Malik K (2014) Human Development Report 2014: Sustaining Human Progress: Reducing Vulnerabilities and Building Resilience. UN Development Programme, New York, NY, USA.

Minke G (2001) Construction Manual for Earthquake-Resistant Houses Built of Earth. Gate - Building Advisory Service and Information Network, Eschborn, Germany.

Nicol F and Humphreys MA (2010) Derivation of the adaptive equations for thermal comfort in free-running buildings in European standard EN15251. Energy and Buildings 45(1): 11-17, https://doi.org/10.1016/ j.buildenv.2008.12.013.

NPA (National Planning Authority) (2010) National Development Plan (2010/11-2014/15). NPA, Kampala, Uganda.

Olweny MRO (1996) Designing a Satisfactory Indoor Environment with Particular Reference to Kampala, Uganda. MSc thesis, University of Adelaide, Adelaide, Australia.
Oughton D and Wilson A (2015) Faber \& Kell's Heating \& Airconditioning of Buildings, 11th edn. Acome, London, UK.

Perez A (2009) Interlocking Stabilised Soil Blocks, Appropriate Earth Technologies in Uganda. UN Human Settlements Programme, Nairobi, Kenya, HS/1184/09E.

Rockwood D, da Silva JT, Olsen S, Robertson I and Tran T (2015) Design and prototyping of a FRCC modular and climate responsive affordable housing system for underserved people in the pacific island nations. Journal of Building Engineering 4: 268-282, https://doi.org/10.1016/j. jobe.2015.09.013.

Rodrigues LT and Gillott M (2013) Climate resilience of a low-energy prototype house. Proceedings of the Institution of Civil Engineers Engineering Sustainability 166(6): 337-350, https://doi.org/10.1680/ ensu.12.00009.

Ruskulis O (2009) Mud as a Mortar, Practical Action. Schumacher Centre for Technology and Development, Rugby, UK.

Thorpe D (2011) Solar Technology: the Earthscan Expert Guide to Using Solar Energy for Heating Cooling and Electricity. Earthscan, London, UK.

Tuohy PG, Humphreys MA, Nicol F, Rijal HB and Clarke JA (2009) Occupant behaviour in naturally ventilated and hybrid buildings. ASHRAE Transactions 115(1): 16-27.

Ubos (Uganda Bureau of Statistics) (2006) 2002 Uganda Population and Housing Census, Analytical Report. Ubos, Kampala, Uganda.

Ubos (2010) Uganda National Household Survey 2009/10. Ubos, Kampala, Uganda.

Ubos (2012) Uganda Demographic and Health Survey 2011. Ubos, Kampala, Uganda.

UN Desa (UN Department of Economic and Social Affairs) (2014) World Urbanization Prospects: the 2014 Revision. UN Desa, New York, NY, USA.

UNDP (UN Development Programme) (2015) Human Development Report 2015: Work for Human Development. UNDP, New York, NY, USA.

UN-Habitat (UN Human Settlements Programme) (2009) Country Programme Document 2008-2009, Uganda. UN-Habitat, Nairobi, Kenya, HS/1112/09E.

UN-Habitat (2010) Climate Change Assessment for Kampala, Uganda: a Summary. UN-Habitat, Nairobi, Kenya.

US DOE (US Department of Energy) (2016) EnergyPlus ${ }^{\mathrm{TM}}$ Version 8.5 Documentation, Input Output Reference. US DOE, Washington, DC, USA.

Wood A and Salib R (2013) Guide to Natural Ventilation in High Rise Office Buildings. Routledge, New York, NY, USA.

Yao J (2013) An investigation into the impact of movable solar shades on energy, indoor thermal and visual comfort improvements. Building and Environment 71: 24-32, https://doi.org/10.1016/j.buildenv.2013.09. 011.

\section{How can you contribute?}

To discuss this paper, please email up to 500 words to the editor at journals@ice.org.uk. Your contribution will be forwarded to the author(s) for a reply and, if considered appropriate by the editorial board, it will be published as discussion in a future issue of the journal.

Proceedings journals rely entirely on contributions from the civil engineering profession (and allied disciplines). Information about how to submit your paper online is available at www.icevirtuallibrary.com/page/authors, where you will also find detailed author guidelines. 